WARSZTATY Z GEOGRAFII TURYZMU

ISBN 978-83-7969-262-0 $\quad$ s. 329-345

http://dx.doi.org/10.18778/7969-262-0.21

Krzysztof PARZYCH

Akademia Pomorska w Słupsku

Alvaro Gervasio GONZALEZ

Instituto Uruguayo de Turismo Sustentable

\title{
WYBRANE UWARUNKOWANIA ATRAKCYJNOŚCI TURYSTYCZNEJ I RUCHU TURYSTYCZNEGO URUGWAJU
}

\section{Wstęp}

Ruch turystyczny na świecie koncentruje się w strefie wybrzeży nadmorskich (AgARWAL, SHAW 2007, BRAMWELl 2004, HALL, PAGE 2006, KOWALCZYK 2001, MATCZAK 2005, KUREK 2007, PARZYCH 2009a, b). Pod względem ilościowym w recepcji ruchu turystycznego dominują kraje basenu Morza Śródziemnego. Oprócz nich istotną rolę odgrywają wybrzeża Morza Karaibskiego oraz regionu Azji i Południowego Pacyfiku. Znacznie mniejszą frekwencją turystyczną charakteryzują się wybrzeża kontynentów afrykańskiego oraz amerykańskiego. Wśród państw regionu amerykańskiego istnieją obszary, które są miejscami koncentracji masowej turystyki wypoczynkowej. Są to m.in. wybrzeża południowo-wschodnie Brazylii (obszar pomiędzy Rio de Janeiro i Sao Paulo), północno-wschodnie wybrzeża Brazylii (Salvador de la Bahia, Fortaleza), wybrzeża Wenezueli (wyspa Margarita), Trynidad i Tobago, pacyficzne wybrzeża Peru (Lima, Callao) oraz Chile (pas nadmorski w regionie Valparaiso-Vina del Mar). Jednym z głównych obszarów najczęś- 
ciej odwiedzanych przez turystów w Ameryce Południowej jest rejon ujścia La Platy. Obszar ten jest jednym $z$ najintensywniej użytkowanych pod względem turystycznym odcinków wybrzeży Ameryki Południowej. Szczególnie ważną rolę wśród innych krajów Ameryki Południowej odgrywa w rozwoju funkcji turystycznej Urugwaj.

\section{Cel i zakres opracowania}

Celem opracowania jest analiza atrakcyjności turystycznej oraz charakterystyka wybranych cech zagospodarowania i ruchu turystycznego Urugwaju. Analizy wybranych cech ruchu turystycznego dokonano w ujęciu dynamicznym wykorzystując dane statystyczne, w ujęciu ogólnym dotyczącym frekwencji turystów zagranicznych w latach 1953-2012 oraz w ujęciu szczegółowym cech charakterystycznych ruchu turystycznego w latach 2003-2012. Jako materiał źródłowy wykorzystano dane statystyczne Ministerstwa Turystyki Urugwaju publikowane w corocznych raportach Annuario de Estedistica de la Republica del Uruguay.

\section{Atrakcyjność turystyczna Urugwaju}

Urugwaj jest położony w południowo-wschodniej części Ameryki Południowej. Pod względem fizycznogeograficznym zajmuje skrajną południowo-wschodnią część Wyżyny Brazylijskiej. Ukształtowanie powierzchni kraju jest w przeważającej mierze nizinne. Najwyższe wysokości bezwzględne wiążą się z niezbyt wysokimi izolowanymi wzniesieniami będącymi fragmentami krystalicznej tarczy brazylijskiej (Cuchilla Grande i Cuchilla de Haedo), których wysokość nieznacznie przekracza 600 m n.p.m. Turystyka w Urugwaju odgrywa znaczącą rolę w rozwoju społeczno-ekonomicznym kraju. Z punktu widzenia atrakcyjności turystycznej najistotniejszą rolę w rozwoju turystyki pełni w Urugwaju obszar wybrzeża. Urugwaj jest położony częściowo wzdłuż wybrzeża La Platy oraz Oceanu Atlantyckiego. Długość linii brzegowej wynosi łącznie ponad $650 \mathrm{~km}$. Wybrzeże w większości reprezentuje typ niski, mierzejowo-zalewowy $\mathrm{z}$ rozległymi piaszczystymi plażami w części zachodniej oraz centralnej, w departamentach Colonia, San 
Jose, Montevideo oraz Maldonado i Canelones. W części wschodniej płaskie mierzejowo-zalewowe wybrzeże jest dodatkowo urozmaicone jeziorami lagunowymi: Laguna de Difuntos, Laguna de Mirim. Urugwaj leży w strefie klimatu podzwrotnikowego typu śródziemnomorskiego, ze stosunkowo łagodną zimą (średnia temperatura lipca wynosi $11^{\circ} \mathrm{C}$ ) oraz ciepłym latem (średnia temperatura stycznia wynosi $23^{\circ} \mathrm{C}$ ). Ponadto klimat Urugwaju charakteryzuje się wysokim usłonecznieniem. Cechy klimatu oraz typ wybrzeża predestynują rozwój turystyki wypoczynkowej w Urugwaju, zwłaszcza w jego południowej, nadatlantyckiej części.

Głównym regionem turystycznym kraju jest teren wybrzeża. Region wybrzeża Urugwaju można podzielić na dwa odrębne obszary: Costa del Oeste rozciągające się od granicy z Argentyną w kierunku wschodnim do Montevideo. Od stolicy Urugwaju Montevideo w kierunku wschodnim rozciąga się wybrzeże Costa del Este. Wybrzeże Costa del Oeste obejmuje pas nadmorski w granicach departamentów Colonia, San Jose oraz Montevideo. Na tym odcinku znajduje się 38 miejscowości nadmorskich. Wybrzeże w regionie Costa del Oeste ma charakter mierzejowo-zalewowy z rozległymi piaszczystymi plażami. Wśród najpopularniejszych miejscowości wypoczynkowych Costa del Oeste można wyróżnić Carmelo, Colonia del Sacramento, Santa Ana, Playa Azul (departament Colonia), Kiyu, Ciudad de La Plata (departament San Jose) oraz Punta de Tigre, Pocitos, Punta Gorda i Carasco (departament Montevideo).

Znacznie lepiej zagospodarowany pod względem turystycznym jest region Costa del Este rozciągający się od stolicy kraju Montevideo w kierunku wschodnim do granicy urugwajsko-brazylijskiej na odcinku $230 \mathrm{~km}$. Ten region wybrzeża $w$ regionalizacji geograficznej Urugwaju jest podzielony na Costa de La Ciudad oraz Costa de Oro i Costa de Rocha. Na wybrzeżu Costa de La Ciudad znajduje się 11 miejscowości wypoczynkowych, z których najpopularniejsze są La Barra del Carasco, San Jose de Carasco, Solymar i El Pinar (tab. 1). W granicach Costa de Oro znajduje się 29 miejscowości wypoczynkowych, z których najistotniejsze z punktu widzenia ich roli recepcyjnej są: Neptunia, Salinas, Atlantida, Las Vegas, La Floresta, Costa Azul, La Tuna, Araminda, Paraiso Suizo.

W obrębie wybrzeża Costa de Maldonado znajdują się 24 miejscowości wypoczynkowe. Na tym obszarze zlokalizowane są główne kurorty nadmorskie rangi międzynarodowej: Playa Hermosa, Punta Negra, Barra del Maldonado, Piriapolis Punta Ballena, La Paloma oraz najbardziej znany kurort nadmorski Urugwaju - Punta del Este. 
Tabela 1. Kąpieliska morskie Urugwaju według departamentów

\begin{tabular}{|c|c|c|c|}
\hline \multicolumn{4}{|c|}{$\begin{array}{l}\text { Odcinek wybrzeża: } \\
\text { Costa del Oeste }\end{array}$} \\
\hline Departament & Colonia & San Jose & Montevideo \\
\hline $\begin{array}{l}\text { Miejscowości } \\
\text { kąpieliskowe }\end{array}$ & $\begin{array}{l}\text { Carmelo, Martín Chico, } \\
\text { Punta Pereyra, Punta Francesa, } \\
\text { San Carlos, Colonia del } \\
\text { Sacramento, Santa Ana, } \\
\text { Riachuelo, Artilleros, } \\
\text { Juan Lacaze, Blanca Arena, } \\
\text { Britópolis, Playa Azul, } \\
\text { Boca del Rosario, Playa Parán, } \\
\text { Fomento, Los Pinos, Brisas del } \\
\text { Plata, Santa Regina }\end{array}$ & $\begin{array}{l}\text { Kiyú, Ordeig, Playa } \\
\text { Pascual, Ciudad } \\
\text { del Plata, Delta del } \\
\text { Tigre }\end{array}$ & $\begin{array}{l}\text { Punta Espinillo, Pajas } \\
\text { Blancas, Punta Yeguas, } \\
\text { Punta del Tigre, } \\
\text { Capurro, Parque Rodó, } \\
\text { Punta Carretas, Pocitos, } \\
\text { Buceo, Malvín, Punta } \\
\text { Gorda, Carrasco }\end{array}$ \\
\hline \multicolumn{4}{|c|}{$\begin{array}{l}\text { Odcinek wybrzeża: } \\
\text { Costa del Este }\end{array}$} \\
\hline Departament & Canelones & Maldonado & Rocha \\
\hline $\begin{array}{l}\text { Miejscowości } \\
\text { kąpieliskowe }\end{array}$ & $\begin{array}{l}\text { Ciudad de la Costa: } \\
\text { La Barra de Carrasco, Parque } \\
\text { Carrasco, Shangrilá, San José } \\
\text { de Carrasco, Lagomar, } \\
\text { El Bosque, Solymar, Parque de } \\
\text { Solymar, Lomas de Solymar, } \\
\text { Médanos de Solymar, El Pinar } \\
\\
\text { Costa de Oro: } \\
\text { Neptunia, Pinamar, Pinepark, } \\
\text { Salinas, Marindia, El Fortín } \\
\text { de Santa Rosa, Villa Argentina, } \\
\text { Atlántida, Las Toscas, Parque } \\
\text { del Plata, Las Vegas, La } \\
\text { Floresta, Costa Azul, Bello } \\
\text { Horizonte, Guazuvirá Nuevo, } \\
\text { Guazuvirá, San Luis, Los } \\
\text { Titanes, La Tuna, Araminda, } \\
\text { Santa Lucía del Este, Biarritz, } \\
\text { Cuchilla Alta, El Galeón, } \\
\text { Sierras del Mar, Santa Ana, } \\
\text { Balneario Argentino, Paraíso } \\
\text { Suizo, Jaureguiberry }\end{array}$ & $\begin{array}{l}\text { Solís, Bella Vista, } \\
\text { Las Flores, Playa Verde, } \\
\text { Playa Hermosa, Playa } \\
\text { Grande, Piriápolis, } \\
\text { Punta Fría, San } \\
\text { Francisco, Punta } \\
\text { Colorada, Punta Negra, } \\
\text { Punta del Este, La Barra } \\
\text { de Maldonado, Laguna } \\
\text { Blanca, Manantiales, } \\
\text { El Chorro, Buenos } \\
\text { Aires, San Vicente, } \\
\text { Edén Rock, Santa } \\
\text { Mónica, La Juanita, } \\
\text { José Ignacio, Arenas } \\
\text { de José Ignacio }\end{array}$ & $\begin{array}{l}\text { La Pedrera, Punta } \\
\text { Rubia, Santa Isabel, } \\
\text { San Antonio, Brisas } \\
\text { del Este, Pueblo Nuevo, } \\
\text { Oceanía del Polonio, } \\
\text { Cabo Polonio, Barra } \\
\text { de Valizas, Aguas } \\
\text { Dulces, La Sirena, } \\
\text { El Cocal, La Esmeralda, } \\
\text { El Buzón, Punta } \\
\text { del Diablo, Santa } \\
\text { Teresa, La Coronilla, } \\
\text { Santa Ana de Mar, } \\
\text { Palmares de la } \\
\text { Coronilla, } \\
\text { Las Maravillas, } \\
\text { La Barra del Chuy }\end{array}$ \\
\hline
\end{tabular}

Źródło: opracowanie własne.

Wybrzeże Costa de Rocha ma w większości charakter lagunowy. Na terenie Costa de Rocha znajduje się 21 miejscowości wypoczynkowych. 
Głównymi kurortami nadmorskimi tego odcinka wybrzeża są: La Pedrera, Punta Rubia, Santa Isabel, Aguas Dulces, Cabo Polonio, Palmares de La Coronila, La Coronilla, Barr del Chuy (tab. 1).

Turystyka w Urugwaju ma charakter wybitnie wypoczynkowy, co wynika z walorów naturalnych predestynujących wykorzystanie wybrzeża kraju w celach turystyczno-rekreacyjnych. Z drugiej strony w Urugwaju jest stosunkowo niewiele innych bardziej spektakularnych walorów turystycznych. Poza walorami wypoczynkowymi w regionie nadmorskim interesujące walory kulturowe związane są z miejscowościami: Colonia del Sacramento, gdzie głównymi walorami są zabytki dziedzictwa historyczno-kulturowego dawnych portugalskich osad kolonialnych, Chuy i Rocha, z fragmentami twierdz obronnych oraz Fray Bentos - w stylu wiktoriańskim, z zabytkową dzielnicą z 1859 r.

Ważną destynacją turystyczną jest ponadto sama stolica kraju - Montevideo, która łączy w sobie walory wypoczynkowe kurortu nadmorskiego oraz liczne zabytki epoki kolonialnej: historyczne centrum: Ciudad Vieja z placem Plaza de la Independencia, cenne zabytki architektury: Palacio Salvo, katedra metropolitalna z XVIII w., kolonialna twierdza obronna u wejścia do portu. Poza regionem wybrzeża kraju ważniejszymi destynacjami turystycznymi są Paysandu - dawna misja jezuicka z 1772 r., Salto - z największym w kraju kompleksem basenów geotermalnych (źródła Salto Grande i Guaviyu o temperaturze $40^{\circ} \mathrm{C}$ ).

W Urugwaju znajduje się kilka parków narodowych - położone poza wybrzeżem: Anchorena, Arequita, Fortaleza de Santa Teresa, Fuerte San Miguel, i najbardziej znany ze względu na jedne z większych kompleksów wydm nadmorskich w Ameryce Południowej - Park Narodowy Cabo Polonio w departamencie Rocha.

Ważnymi elementami atrakcyjności turystycznej Urugwaju są ponadto imprezy kulturalne, stanowiące element jego tożsamości i dziedzictwa. Wśród nich największą rolę odgrywa karnawał z kulminacyjną dwudniową zabawą ogólnonarodową. Znanym świętem związanym silnie z tożsamością narodową mieszkańców Urugwaju jest ponadto Fiesta de La Patria Gaucho święto ojczyzny gauczowskiej, którego centrum stanowi miejscowość Tacuarembo w środkowej części kraju.

Dużą atrakcją, zwłaszcza dla turystów zagranicznych, jest ponadto szeroko kultywowany wśród Urugwajczyków Candombe, który stanowi element dziedzictwa afro-urugwajskiej części społeczeństwa Urugwaju i syntezę spotkań mieszkańców urugwajskich miast, pochodów i parad ulicznych po- 
łączonych z grą na bębnach tambores oraz z tańcem. Społeczną oraz historyczno-kulturową rangę tego waloru podkreśla włączenie w 2009 r. muzyki Candombe i jej szeroko rozumianej przestrzeni społeczno-kulturowej na Listę Niematerialnego Dziedzictwa UNESCO.

\section{Wybrane cechy zagospodarowania turystycznego Urugwaju}

Głównym regionem turystycznym kraju jest wybrzeże tzw. urugwajska riwiera. Rozwój turystyki wypoczynkowej w Urugwaju wiąże się przede wszystkim z miejscowością Punta del Este. Miasto zostało założone w1829 r. przez Francisco Aguilara jako Vila Izutaingo i początkowo funkcjonowało jako ośrodek rolnictwa, rybołówstwa, w tym związanego z połowem wielorybów, oraz ośrodek produkcji ceramiki. Rozwój turystyki w Punta del Este rozpoczyna się w $1889 \mathrm{r}$. z budową pierwszego hotelu. W kolejnych latach baza noclegowa kurortu uległa znacznej rozbudowie stając się dominującą funkcją w rozwoju społeczno-ekonomicznym miejscowości. Aktualnie Punta del Este jest najlepiej zagospodarowaną pod względem infrastruktury noclegowej miejscowością wypoczynkową kraju oraz jednym z najpopularniejszych kurortów nadmorskich zachodniej półkuli. Zagospodarowanie turystyczne kurortu koncentruje się na zapleczu dwóch najintensywniej użytkowanych przez turystów plaż Playa Mansa i Playa Brava.

Analiza ilościowa bazy recepcyjnej turystyki w Urugwaju wskazuje na silne dysproporcje przestrzenne (rys. 1). W roku $2012 \mathrm{w}$ Urugwaju znajdowało się 457 obiektów hotelarskich, z tego 185 (ponad 34\% ogółu) było zlokalizowanych $\mathrm{w}$ kurortach nadmorskich departamentu Maldonado (przede wszystkim w Punta del Este, Punta Ballena, La Paloma, Piriapolis), a 19\% (85 obiektów) w departamencie stołecznym Montevideo. Ponadto 57 hoteli znajdowało się w departamencie Rocha (12,5\% ogółu bazy hotelowej kraju), a 38 obiektów w departamencie Colonia. Ogółem we wszystkich departamentach nadmorskich Urugwaju było zlokalizowane ponad 80\% całej bazy hotelarskiej kraju. Poza regionem nadmorskim było zaledwie $20 \%$ bazy hotelowej, z tego najwięcej w departamencie Salto (27 obiektów, około 6,0\% bazy noclegowej kraju). 


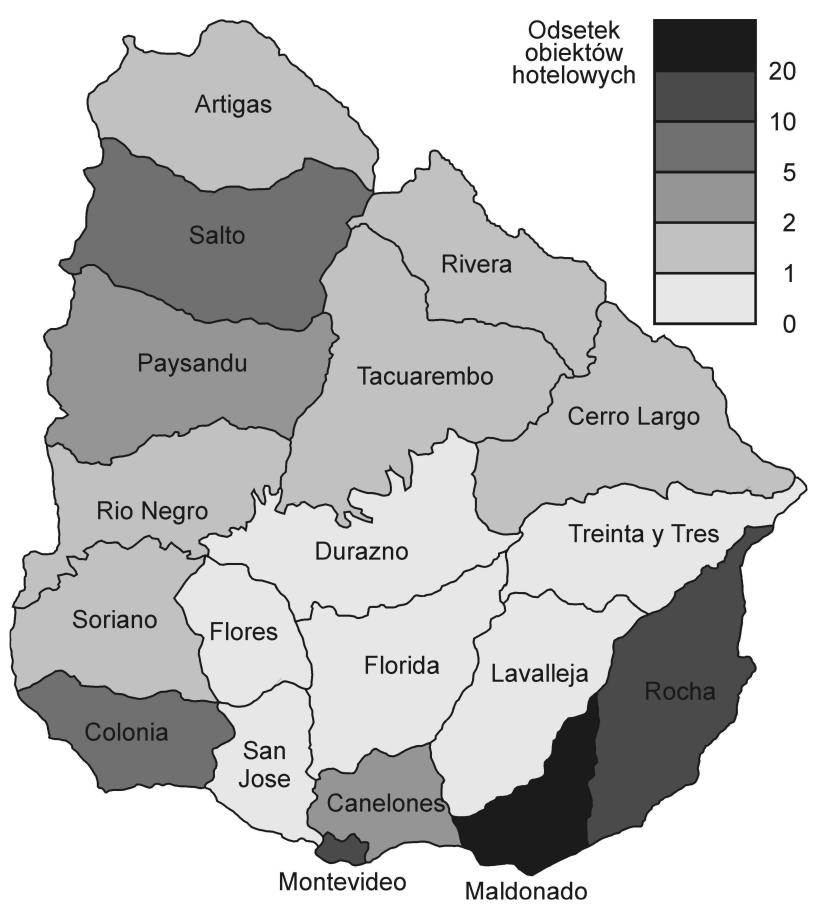

Rys. 1. Rozmieszczenie obiektów bazy hotelowej na obszarze Urugwaju Źródło: opracowanie własne na podstawie Annuario Estadistico del Uruguay (2013)

Oprócz bazy hotelowej ważnym elementem struktury rodzajowej bazy noclegowej Urugwaju są obiekty apartamentowe. Ogółem w kraju w roku 2012 funkcjonowało ich 543. Wszystkie były zlokalizowane w strefie wybrzeża. Najwięcej obiektów apartamentowych było zlokalizowanych w departamencie Maldonado (364 - 67\% ogółu takich obiektów w Urugwaju), w departamentach: Colonia (57 - 10\%), Canelones (49 - 9\%) i Montevideo (40 obiektów - 7,4\%).

Region wybrzeża jest również głównym obszarem koncentracji działalności związanej z obsługą i organizacją ruchu turystycznego. W roku 2012 w Urugwaju funkcjonowało 469 tego typu instytucji. Z tego najwięcej, bo prawie $60 \%$ (277), znajdowało się w stołecznym departamencie Montevideo, znacznie mniej w departamencie Maldonado (57 instytucji, 12,2\% ogółu organizatorów turystyki w Urugwaju), a w departamentach Canelones i Colonia odpowiednio: 28 (6\%) i $23(4,9 \%)$. 


\section{Ruch turystyczny w Urugwaju}

Urugwaj należy do najczęściej odwiedzanych krajów amerykańskiego regionu turystycznego. W roku 2012 liczba turystów zagranicznych w kraju wyniosła 2695 tys. (rys. 2, tab. 2).

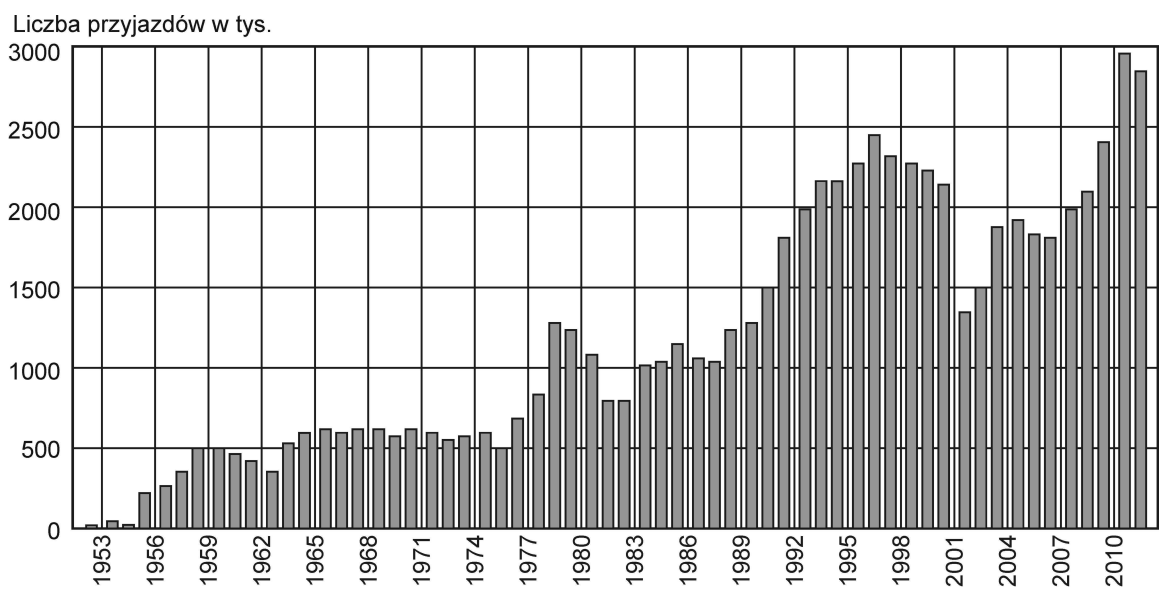

Rys. 2. Przyjazdy turystów zagranicznych do Urugwaju w latach 1953-2012 Źródło: opracowanie własne na podstawie Annuario Estadistico del Uruguay (2013)

Tabela 2. Wskaźniki względnej siły przyciągania turystycznego krajów Ameryki Południowej

\begin{tabular}{|c|c|c|c|c|}
\hline \multirow[b]{2}{*}{ Państwo } & \multicolumn{3}{|c|}{ Liczba } & \multirow{2}{*}{$\begin{array}{l}\text { Wskaźnik względnej } \\
\text { siły przyciągania } \\
\text { turystycznego }\end{array}$} \\
\hline & $\begin{array}{l}\text { turystów } \\
\text { (T) }\end{array}$ & $\begin{array}{l}\text { ludności } \\
\text { (L) }\end{array}$ & $\begin{array}{l}\text { turystów przypadających } \\
\text { na } 1 \text { mieszkańca } \mathrm{T} / \mathrm{L}\end{array}$ & \\
\hline Argentyna & 5599000 & 40913584 & 0,136849 & 13,68 \\
\hline Boliwia & 946000 & 9775246 & 0,096775 & 9,68 \\
\hline Brazylia & 5677000 & 198739269 & 0,028565 & 2,86 \\
\hline Chile & 3554000 & 16601707 & 0,214074 & 21,41 \\
\hline Kolumbia & 2175000 & 43677372 & 0,049797 & 4,98 \\
\hline Ekwador & 1272000 & 14573101 & 0,087284 & 8,73 \\
\hline Gujana & 157000 & 752940 & 0,208516 & 20,85 \\
\hline Paragwaj & 579000 & 6995655 & 0,082766 & 8,28 \\
\hline Peru & 2846000 & 29546963 & 0,096321 & 9,63 \\
\hline Surinam & 240000 & 481276 & 0,498674 & 49,87 \\
\hline Urugwaj & 2695000 & 3494382 & 0,771238 & 77,12 \\
\hline Wenezuela & 710000 & 26814843 & 0,026478 & 2,65 \\
\hline
\end{tabular}

Źródło: opracowanie własne na podstawie Annuario Estadistico del Uruguay (2013). 
Według statystyk w 2012 r. Urugwaj był piątym najczęściej odwiedzanym państwem Ameryki Południowej po Brazylii, Argentynie, Chile i Peru. W celu oceny rzeczywistej siły przyciągania turystycznego dokonano obliczenia wskaźnika względnej siły przyciągania turystycznego Urugwaju na tle innych krajów Ameryki Południowej. Wartość wskaźnika pokazuje, że Urugwaj charakteryzował się najwyższą względną siłą przyciągania turystycznego na tle innych państw Ameryki Południowej. Wartość wskaźnika wyniosła dla Urugwaju 77 i była znacznie wyższa od wszystkich pozostałych państw Ameryki Południowej (tab. 2).

Analiza ruchu turystycznego i dynamiki przyrostu liczby turystów w latach 1953-2012 w Urugwaju wskazuje na jednostajny niemalże w całej rozciągłości badanego okresu przyrost liczby turystów zagranicznych. Szczególną dynamikę można zaobserwować w odniesieniu do lat 1983-2001 oraz 2008-2013 (rys. 2).

W badanym przedziale czasowym odnotowano też kilkuletnie okresy spadków liczby turystów w stosunku do lat ubiegłych. Były to lata 1981 -1982 oraz rok 2003. Pierwszy z tych okresów należy wiązać prawdopodobnie $\mathrm{z}$ konfliktem argentyńsko-brytyjskim w związku ze sporem o FalklandyMalwiny. Działania zbrojne, w których uczestniczyła Argentyna, miały wpływ na spadek zainteresowania turystów zagranicznych tym krajem, a także wpłynęły na ogólnie mniejszą liczbę turystów w całej Ameryce Południowej, szczególnie można było odczuć to w sąsiednim Urugwaju.

Drugi wyraźniejszy spadek w dynamice przyrostu liczby turystów w Urugwaju wiąże się z rokiem 2003 i można przypuszczać, że związany był z kryzysem ekonomicznym w sąsiedniej Argentynie, która jest głównym rynkiem emisyjnym turystyki w Urugwaju.

W pozostałych latach badanego okresu 1953-2012 zaznacza się systematyczny wzrost ruchu turystycznego aż do roku 2011, kiedy odnotowano rekordową liczbę turystów 2890 tys. W roku 2012 liczba turystów, którzy odwiedzili Urugwaj nieznacznie się obniżyła i wyniosła 2690 tys.

Urugwaj graniczy z Brazylią na długości $985 \mathrm{~km}$ oraz z Argentyną na długości 579 km. Granice mają w większości charakter naturalny. Z Brazylią przebiegają głównie wzdłuż dolin rzecznych (Urugwaju i jego dopływów, dopływów rzeki Rio Negro oraz mniejszych rzek należących do dorzeczy Laguny Patos i Mirim), z Argentyną granicą są wody La Platy.

Analiza miejsc przekraczania granicy przez turystów zagranicznych przybywających do Urugwaju w latach 2003-2012 wskazuje, że najwięcej 
osób docierało do Urugwaju do miejscowości Colonia del Sacramento. Średnio w badanym okresie było to ponad 500 tys. turystów rocznie. Innymi częstymi miejscami przekraczania granicy urugwajskiej przez turystów zagranicznych w badanym okresie były Port Lotniczy Carasco (port Montevideo) oraz położona nad La Platą miejscowość Fray Bentos. Ponadto turyści zagraniczni przybywali do Urugwaju od strony zachodniej, drogą lądową przez Salto i Paysandu.

Analiza środków transportu wykorzystywanych przez turystów zagranicznych $\mathrm{w}$ podróży do Urugwaju, w trakcie penetracji turystycznej kraju oraz w podróży powrotnej do kraju pochodzenia, wskazuje na znaczne ich zróżnicowanie. Wynika ono ze specyfiki granic kraju, które mają w dużej mierze charakter naturalny i znacznie bardziej niż w innych regionach świata ograniczają wykorzystanie transportu samochodowego.

W roku 2012 najwięcej, bo ponad 47\% turystów dotarło do Urugwaju drogą lądową. Z uwagi na specyfikę granic Urugwaju z krajami sąsiednimi znaczna część spośród 2,7 mln turystów zagranicznych przybyła tu transportem rzecznym (Fray Bentos, Colonia). Ponadto blisko 20\% turystów dotarło do Urugwaju samolotem, przede wszystkim do stolicy kraju Montevideo, które ma regularne połączenia lotnicze $\mathrm{z}$ dużymi portami lotniczymi krajów sąsiednich oraz z pozostałymi państwami Ameryki Południowej i z wybranymi dużymi portami lotniczymi Europy (Madryt, Paryż, Rzym).

Analiza pochodzenia turystów zagranicznych odwiedzających Urugwaj w latach 2003-2012 wskazuje na zdecydowaną dominację turystów z sąsiedniej Argentyny, których w badanym okresie przyjeżdżało do Urugwaju średnio blisko 1400 tys., co stanowiło ponad połowę wszystkich turystów zagranicznych w kraju.

Warto odnotować, że udział turystów argentyńskich odwiedzających Urugwaj w badanym okresie według oficjalnych statystyk Ministerstwa Turystyki Urugwaju był wyższy niż turystów krajowych, których w badanym okresie odnotowywano średnio od 350 do 400 tys. rocznie. Wśród pozostałych turystów zagranicznych odwiedzających Urugwaj byli turyści z Brazylii, średnio ponad 200 tys. rocznie, spoza krajów Ameryki Południowej, głównie ze Stanów Zjednoczonych oraz z niektórych państw europejskich (Hiszpanii, Włoch, Niemiec, Wielkiej Brytanii), a także z Chile i Paragwaju.

Taki rozkład przestrzenny pochodzenia turystów wynika $\mathrm{z}$ położenia kraju. Z uwagi na niewielką odległość oraz stosunkowo dogodne połączenia w komunikacji promowej umożliwiające szybkie przejazdy na pobyty wypoczynkowe, ale również odbywanie krótkich wycieczek kilkudniowych, a na- 
wet wyjazdy jednodniowe (promy Buenos Aires-Colonia, Buenos Aires -Montevideo) Urugwaj był najczęściej odwiedzany przez turystów z sąsiedniej Argentyny (rys. 3). Ponadto częściej był odwiedzany przez turystów z innych państw Ameryki Południowej, takich jak: Brazylia, Chile i Paragwaj. Znacznie mniejszą populację wśród turystów zagranicznych z uwagi na konieczność korzystania wyłącznie z transportu lotniczego w podróży do Urugwaju stanowili turyści z państw innych kontynentów.

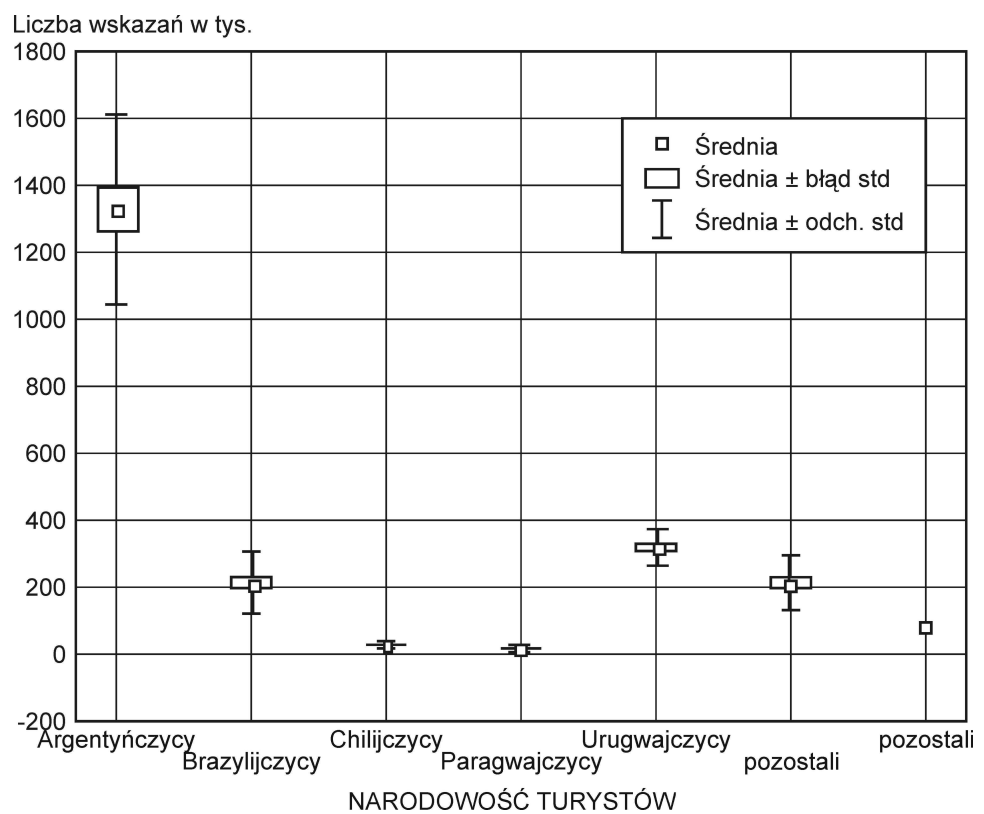

Rys. 3. Dominujące narodowości turystów przyjeżdżających do Urugwaju w latach 2003-2012

Źródło: opracowanie własne na podstawie Annuario Estadistico del Uruguay (2013)

Analiza dominujących destynacji turystów w Urugwaju wskazuje na silną koncentrację przestrzenną ruchu turystycznego (rys. 4). Ponad $27 \%$ turystów jako docelowe miejsce wizyty w Urugwaju wskazało na Montevideo. Natomiast blisko $25 \%$ ogółu turystów jako cel wizyty wskazywało Punta del Este, $17 \%$ inne miejscowości wypoczynkowe regionu Litoral Termal, a około 10\% miejscowość Colonia del Sacramento. Warto jednocześnie odnotować, 
że dla ponad 90\% turystów odwiedzających Urugwaj celem wizyty były miejscowości nadmorskie (wraz ze stolicą) wybrzeża.

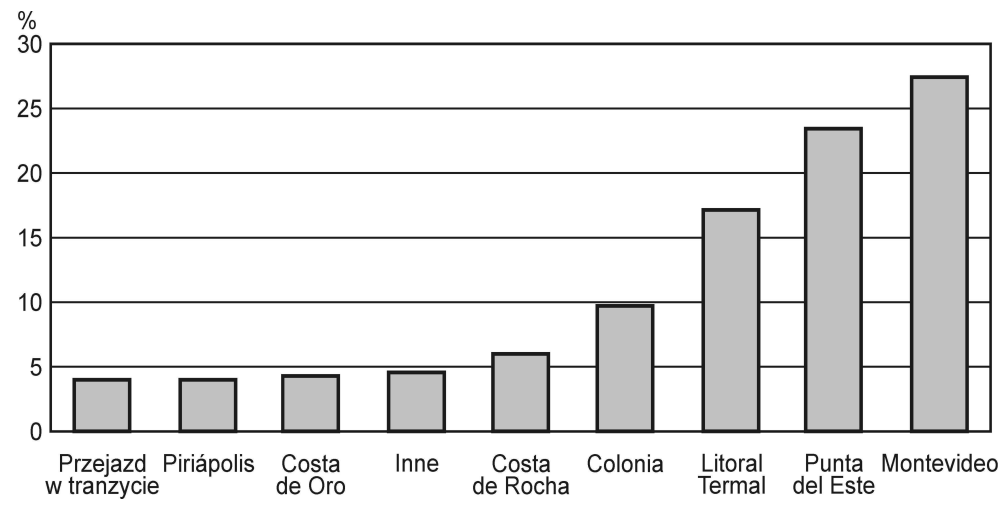

Rys. 4. Dominujące docelowe destynacje turystów zagranicznych w trakcie pobytu w Urugwaju w 2012 r.

Źródło: opracowanie własne na podstawie Annuario Estadistico del Uruguay (2013)

Identyfikacja motywacji turystów odwiedzających Urugwaj w latach 2003-2012 potwierdza wcześniejsze spostrzeżenia o wybitnie wypoczynkowym charakterze turystyki kraju (rys. 5). Zdecydowana większość wskazań dotyczących motywacji przyjazdu wśród turystów przybywających do tego kraju w badanym okresie dotyczyła celów wypoczynkowych. Na ten motyw wskazywała średnio ponad połowa wszystkich turystów. Innym częściej deklarowanym motywem podróży była wizyta u znajomych lub rodziny, na którą wskazywało średnio około 400 tys. turystów rocznie. Pozostałe cele wizyt jak zdrowotne, służbowe, sportowe, biznesowe pojawiały się znacznie rzadziej.

Analogicznie najczęściej wskazywanymi formami aktywności realizowanymi w trakcie pobytów turystów w Urugwaju były aktywność rekreacyjna (ok. 35\% wskazań), odwiedziny krewnych i znajomych (ok. 16\% wskazań, rys. 6). W dalszej kolejności turyści wymieniali odwiedziny cennych atrakcji przyrodniczych kraju, plażowanie, zakupy oraz uczestnictwo w imprezach kulturalnych. Pozostałe formy aktywności były deklarowane przez turystów znacznie rzadziej. 


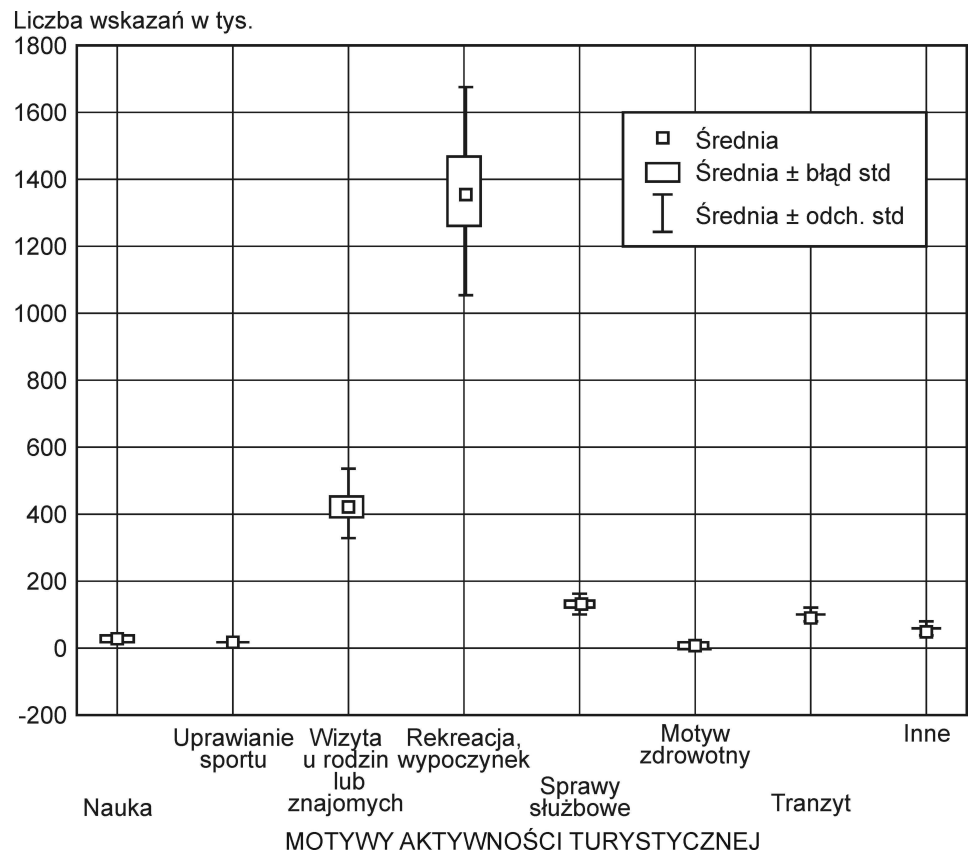

Rys. 5. Częstość motywów realizowanej aktywności turystycznej przez turystów przyjeżdżających do Urugwaju w latach 2003-2012 Źródło: opracowanie własne na podstawie Annuario Estadistico del Uruguay (2013)

Rekreacja
Odwiedziny krewnych i znajomych
Odwiedziny atrakcji przyrodniczych
Plażowanie
Zakupy
Uczestnictwo w imprezach kulturalnych
Zwiedzanie zabytków
Inne formy aktywności
Wizyty w muzeach, galeriach
Sport
Sprawy służbowe
Uczestnictwo w kongresach

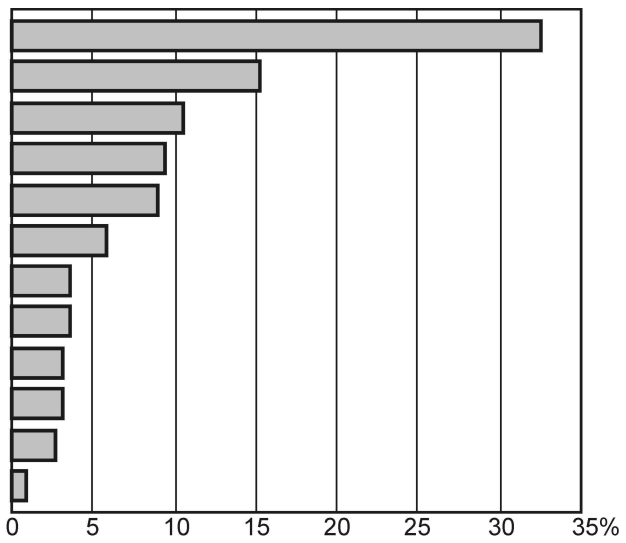

Rys. 6. Najczęściej wskazywane formy aktywności realizowane w trakcie pobytów turystów zagranicznych w Urugwaju Źródło: opracowanie własne na podstawie Annuario Estadistico del Uruguay (2013) 
Zaledwie 5\% turystów wskazywało inne destynacje swoich podróży na terytorium Urugwaju. Analiza dominujących destynacji turystycznych w przyjazdach do Urugwaju w latach 2003-2012 świadczy o niewielkich zakresach zmian liczby turystów $\mathrm{w}$ dominujących kierunkach przyjazdów. Najczęściej wskazywana destynacja, jaką w badanym okresie było Montevideo, była odwiedzana przez średnio 700 tys. turystów rocznie, kolejna Punta del Este przez blisko 600 tys. turystów, miejscowości wypoczynkowe regionu Litoral Termal przez blisko 250 tys., a Colonia del Sacramento przez około 200000 turystów rocznie.

Analiza form zakwaterowania, z których korzystali turyści przyjeżdżający do Urugwaju jest pochodną z jednej strony struktury rodzajowej bazy noclegowej kraju, w której zdecydowanie dominują obiekty hotelarskie, z drugiej strony jest efektem motywacji przyjazdów do Urugwaju, wśród których dominował motyw wypoczynkowy oraz motyw odwiedzin krewnych i znajomych. Najczęściej wskazywanymi formami zakwaterowania w trakcie pobytów turystów zagranicznych w Urugwaju były noclegi w hotelach oraz u rodziny i znajomych (rys. 7). Średnio 800 tys. turystów w badanym okresie korzystało z noclegu u znajomych, a 750 tys. z noclegu w hotelu. Wśród pozostałych zaznacza się blisko 200 tys. grupa turystów, którzy korzystali z wynajętego mieszkania lub z noclegu w drugim domu.

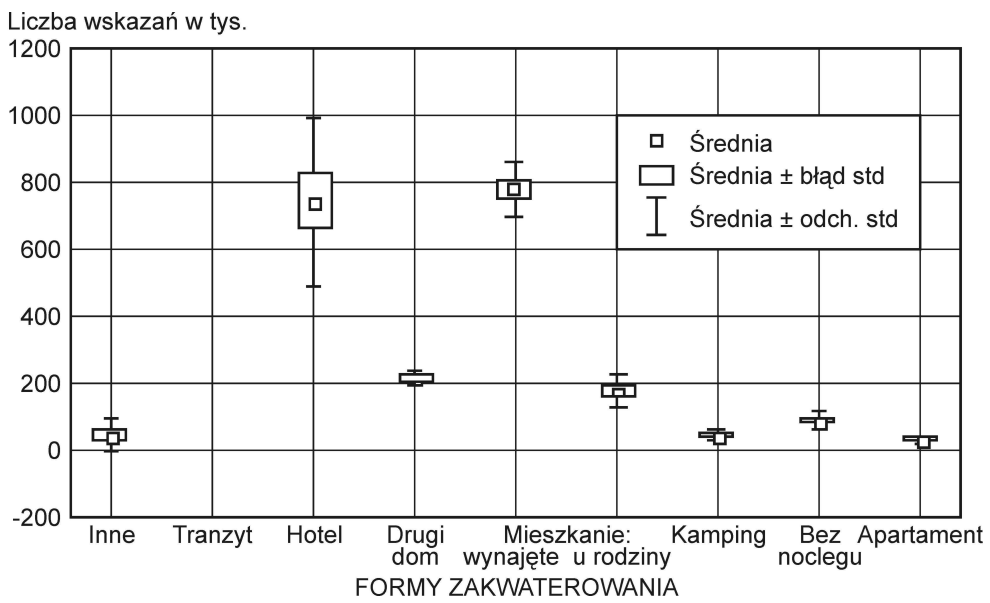

Rys. 7. Formy zakwaterowania wykorzystywane w trakcie pobytów zagranicznych turystów przebywających w Urugwaju

Źródło: opracowanie własne na podstawie Annuario Estadistico del Uruguay (2013) 
Analiza średnich długości pobytów turystów w najpopularniejszych destynacjach turystycznych kraju w badanym okresie wskazuje, że najdłuższe pobyty dotyczyły wizyt w Costa de Rocha (średnio 10 dni w badanym okresie 2003-2012), Piriapolis (9,8 dni), Punta del Ester (9 dni) i Costa de Oro (8,2 dni). Najkrótsze średnie długości pobytu odnotowano dla Colonia del Sacramento i miejscowości wypoczynkowych obszaru Litoral Termal.

$\mathrm{W}$ obu przypadkach określone średnie długości pobytu w badanym okresie wyniosły 4,5 dni.

Architektura
Czystość
Inne
Krajobrazy, plaże, tereny zielone
Ludzie, gościnność, serdeczność
Miasto jako całość
Miasto Montevideo
Rynek miejski
Plaże, promenada spacerowa, wybrzeże
Sklepy i handel
Spokój, poczucie bezpieczeństwa
Stare Miasto
Walory miejscowej kuchni
Odsetek wskazywanych atrakcji
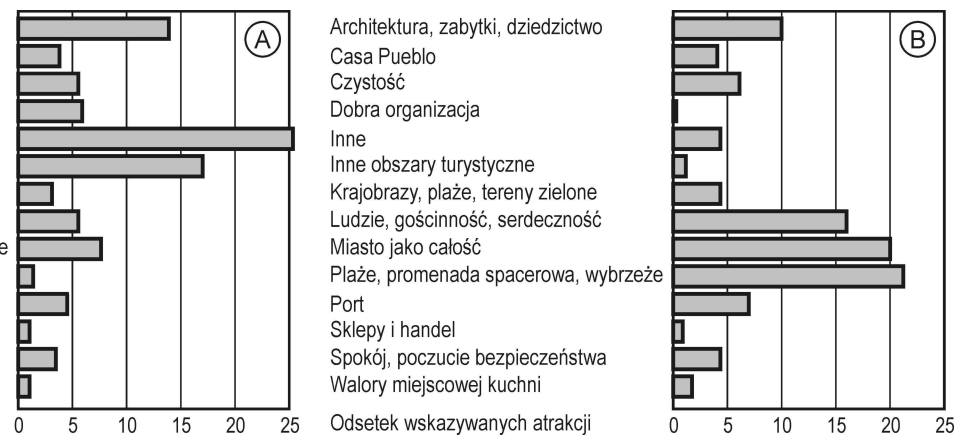

Rys. 8. Najczęściej wskazywane atrakcje turystyczne Montevideo (A) i Punta del Este (B) przez turystów przyjeżdżających do Urugwaju Źródło: opracowanie własne

Najczęściej odwiedzane przez turystów zagranicznych w Urugwaju są Montevideo oraz Punta del Este. Analiza najliczniej wymienianych elementów wizerunku dwóch najpopularniejszych destynacji turystycznych w Urugwaju pozwala zaobserwować znaczne podobienstwa w percepcji ich przestrzeni turystycznej (rys. 8A, B). W przypadku obu destynacji bardzo ważnym elementem atrakcyjności turystycznej są miejscowe społeczności, gościnność, serdeczność mieszkańców. W odniesieniu do Punta del Este głównym elementem atrakcyjności turystycznej kurortu w opinii turystów jest atrakcyjne nadmorskie położenie na półwyspie, rozległe piaszczyste plaże oraz sąsiadujące z nimi tzw. ramble - nadmorskie promenady wraz $\mathrm{z}$ ich zagospodarowaniem i deptakiem spacerowym. 


\section{Podsumowanie}

Przeprowadzona analiza uwarunkowań funkcjonowania turystyki w Urugwaju pozwala na sformułowanie następujących wniosków:

1. Urugwaj jest jednym z krajów o wyjątkowej sile oddziaływania turystycznego na tle innych krajów Ameryki Południowej, czego potwierdzeniem jest relatywnie wysoka skala frekwencji turystycznej i wysoka dynamika jej wzrostu w niemalże całym okresie ostatnich 50 lat.

2. Przestrzeń turystyczna Urugwaju ze względu na dominujący charakter walorów turystycznych oraz korzystne cechy klimatu jest predestynowana przede wszystkim do uprawiania typowej turystyki wypoczynkowej typu $3 \mathrm{~S}$.

3. Urugwaj posiada zagospodarowanie turystyczne przystosowane do recepcji turystyki wypoczynkowej.

4. Najlepiej zagospodarowanym regionem turystycznym kraju jest wybrzeże, tzw. riwiera urugwajska, na obszarze, której znajduje się $80 \%$ całej bazy hotelowej kraju.

5. Głównym obszarem recepcyjnym kraju są nadmorskie kurorty turystyczne wybrzeży Costa de Rocha, Costa del Maldonado oraz Costa de Oro, a najczęściej odwiedzanymi kurortami nadmorskimi Punta del Este, Montevideo, miejscowości wypoczynkowe Litoral Termal oraz Colonia del Sacramento.

6. Wśród turystów odwiedzających Urugwaj dominują przede wszystkim odwiedzający z sąsiednich państw, głównie z Argentyny i Brazylii, w mniejszym stopniu z Chile, Paragwaju oraz z zamorskich krajów europejskich i USA.

7. Ze względu na specyficzne położenie i naturalny charakter granic Urugwaj jest odwiedzany przez turystów korzystających z dróg wodnych oraz transportu lotniczego.

8. Pobyty turystów w Urugwaju mają przede wszystkim charakter wypoczynkowy, czego dowodem są motywy podejmowanych podróży, formy aktywności turystycznej realizowane $\mathrm{w}$ trakcie pobytu oraz średnie długości pobytu turystów w Urugwaju i wykorzystywane środki transportu. 


\section{LITERATURA}

Agarwal S., SHAW G., 2007, Managing Coastal Tourism Resorts. A Global Perspective, Channel View Publications.

BRAMwell B., 2004, Coastal Mass Tourism: Diversification and Sustainable Development in Southern Europe, Channel View Publications.

HALL C.M., PAGE S.J., 2006, The geography of tourism and recreation, London, ss. 427.

KOWALCZYK A., 2001, Geografia turyzmu, PWN, Warszawa, ss. 287.

MATCZAK A., 2005, Tourism in the urban space of the Polish seaside resort of Ustka, „Turyzm”, 15, 1-2.

KUREK W., 2007, Turystyka, PWE, Warszawa.

PARZYCH K., 2009a, Range of the spatial influence and tourist perception of the Polish coastal resort exemplified by Ustka, „Balic Coastal Zone”, 13.

PARZYCH K., 2009b, Perception of the seaside resort in tourist opinion on example of Łeba resort, "The Problems of Landscape Ecology", XXV.

Annuario de Estadistica de la Republika del Uruguay, 2013, Ministerio de Turismo del Uruguay.

\section{SELECTED DETERMINANTS OF TOURIST ATTRACTIVENESS AND TRAFFIC IN URUGUAY}

Key words: tourist traffic, Uruguay, tourist values, tourist attractiveness

\section{Summary}

The tourist traffic in the global scale concentrates in the coastal regions. The most visited coastal region is Mediterranean countries. There are a lot of coastal places in others regions of South American, Asian and Pacific and African countries.

In the article was taken an issue of the determinants of tourism functioning in Uruguay especially in relation to the coastal zone of this country. The analysis was made basing of the statistic data from the Annuario Estadistico del Uruguay 2013. The results show Uruguay have the most tourist attractive force among the others Latin American countries. The most developed tourist region of the Uruguay is the coastal region in south part of the country. There are about $80 \%$ of the tourist accommodation places in the coastal region.

The most visited region by tourists in Uruguay are regions of Costa de Rocha, Costa del Maldonado and Costa de Oro. The most visited destinations are Punta del Ester, Montevideo, health resorts of region Litoral Termal and very famous historic place in the country Colonia del Sacramento. 